\title{
Penataan Lingkungan Kantor Desa Caturharjo Kecamatan Pandak Kabupaten Bantul
}

\author{
Nimas Sekarlangit ${ }^{1}$, Amos Setiadi $^{2}$, , Riana Novita Rachmanti Putri ${ }^{3}$ \\ 1,2,3 Departemen Arsitektur, Fakultas Teknik, Universitas Atma Jaya Yogyakarta \\ Email:nimas.sekarlangit@uajy.ac.id ${ }^{1}$
}

\author{
Received: September 29th 2021 ; Revised: -; Accepted for Publication Descember 17 $7^{\text {th }}$ 2021; Published: January $3^{\text {rd }} 2022$
}

\begin{abstract}
Desa Caturharjo mulai dikembangkan menjadi Kawasan Desa Wisata dengan membedayakan masyakarat secara terpadu. Desa wisata tersebut di kembangkan oleh pemerintah, sawsta dan masyarakat dengan melakukan secara gotong royong. Desa Caturharjo memiliki potensi yang dapat dikembangkan sebagai destinasi wisata. Pengabdian pada Masyarakat dilaksanakan bersama mitra berupa penataan desain lingkungan kantor desa Caturharjo yaitu penataan Kawasan alun-alun. Penataan Kawasan Alun-alun berkonsep pada arsitektur tropis. Hal ini dikarenakan desa Caturharjo yang berada di wilayah Daerah Istimewa Yogyakarta ingin tetap melestarikan material local dan pemanfaatan penghawaan alami dan pencahayaan alami untuk mengurangi penggunaan energi. Pengabdian yang dilakukan menggunakan metode pendekatan terhadap pihak desa dengan melakukan observasi, wawancara dan analisis. Analisis yang dilakukan adalah analisis SWOT terhadap fasilitas yang ada di desa Caturharjo. Analisis dilakukan untuk mengetahui kekuatan dan kelemahan dari desa tersebut. Hasil pengabdian masyarakat ini diharapkan dapat berupa desain penataan lapangan desa sebagai alun-alun desa. Pekarangan kemungkinan akan menjadi identitas caturharjo Desa. Masyarakat sekitar diharapkan dapat dimanfaatkan sebagai ruang publik. Hasilnya sarana penunjang yang terdiri dari kawasan kuliner, area duduk, area air mancur, gazebo, dan lapangan sepak bola mini.
\end{abstract}

Keywords - Desain, Fasilitas, Lingkungan, Desa Caturharjo.

\section{PENDAHULUAN}

Pendahuluan merupakan penjelasan lebih rinci dari dibahas di bagian abstrak di atas (Regular, Times New Roman, 10 pt, spasi tunggal). Berisi tentang pengabdian yang telah dilakukan. Hasil pengabdian berkaitan dengan topik artikel dan atau berita-berita terkini yang menjadi latar belakang mengapa pengabdian dilakukan, rumusan permasalahan, serta tujuan pengabdian dan novelty dari pengabdian yang dilakukan.

Kabupaten Bantul memiliki luas wilayah 50.685 ha, terbagi atas 17 kecamatan yang terdiri dari 75 desa dan 933 pedukuhan. Saat ini Kabupaten Bantul sedang melakukan pembangunan menyeluruh dalam berbagai sektor, terutama di sektor pariwisata. Pada tahun 2018 Kabupaten Bantul menyusun Master Plan Bantul Smart City dan berfokus pada Smart Branding Pariwisata Bantul [1].

Desa Caturharjo mulai dikembangkan menjadi Kawasan Desa Wisata dengan membedayakan masyakarat secara terpadu. Desa wisata tersebut di kembangkan oleh pemerintah, sawsta dan masyarakat dengan melakukan secara gotong royong. Saat ini potensi yang ada Desa Caturharjo adalah potensi alam, sumber daya manusia (pengrajin batik ata wayang atau warangka keris), serta tradisi gotong royong.
Berdasarkan potensi tersebut, maka Desa Catuharjo dapat dikembangkan menjadi Desa wisata. Saat ini Desa Caturharjo mulai berbrnah untuk menyiapkan wilayahnya menjadi sebuah desa wisata yang mampu memneripa wisatawan dari wilayah lain. Selain persiapan terhadap tempat wisata, desa Caturharjo juga mulai mempersiapkan gerbang utama wisata, yaitu area alun-alun desa. Alun-alun Desa berasa di kantor desa yang terletak di wilayah paling depan dari Kawasan Desa Caturharjo.

Penataan lingkungan kantor Desa Caturharjo yang saat ini berupa lapangan yang belum tertata menjadi Alun-alun desa Caturharjo melalui kegiatan Pengabdian Pada Masyarakat ini untuk menghasilkan rancangan (disain) penataan lingkungan kantor desa sehingga diharapkan dapat menjadi identitas desa Caturharjo.
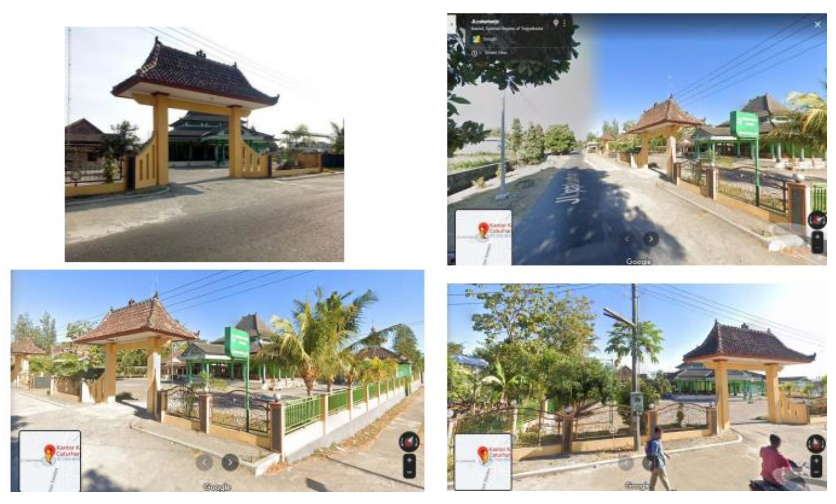

Gambar 1 Lingkungan Alun-alun Desa Caturharjo

Rancangan alun-alun Desa Caturharjo mengarah pada pertimbangan kelestarian lingkungan akan tetapi tetap mempertimbangkan prinsip teknologi mulai dari saat proses pembangunan [2]. Pada perancangan area alun-alun juga harus mengetahui karakteristik lingkungan terutama iklim dan aspek aklimatisasi dan pengaruh sinar matahari terhadap lingkungan [3] [4]. Langkah selanjutnya adalah pemilihan material dengan memilih material yang hemat energi dan tidak menghasilkan racun [5], hal tersebut merupakan disain yang merespon kualitas lingkungan hidup [6]. Oleh sebab itu dengan adanya penataan alun-alun dapat menjadi penanda utama dari kantor desa Caturharjo. Karena Alun-alun sebagai tempat rekreasi merupakan salah satu pembentuk brand suatu wilayah [7].

Kenyamanan termal merupakan ciri arsitektur tropis sebagai solusi untuk mencegah panas matahari masuk ke dalam bangunan. Langkah termudah untuk mendapatkan 
kenyamanan termal adalah dengan mendesain sebuah bangunan dengan memperhatikan orientasi matahari, pemanfaatan elemen, dan material bangunan, dan elemen lansekap [8]. Penerapan shading pada fasad juga dapat berfungsi sebagai penahan panas. Selain itu, atap miring dan ventilasi silang juga menjadi prioritas bangunan tropis untuk mengalirkan air hujan dan udara dengan baik [9]. Permukaan reflektif yang ditempatkan pada fasad seperti kisi-kisi adalah alternatif yang baik untuk mengurangi paparan matahari [10].

Penggunaan ventilasi alami juga mampu menghemat energi dengan tetap mempertahankan kenyamanan thermal. Ventilasi alami adalah teknologi yang berkelanjutan, hemat energi, dan bersih yang dapat diterima dengan baik oleh penghuni. Ini dapat digunakan untuk menyediakan udara segar bagi penghuni jika diperlukan, untuk mempertahankan tingkat kualitas udara yang dapat diterima dan untuk mendinginkan bangunan jika kondisi iklim memungkinkan. Keberhasilan penerapan teknik ventilasi alami dan efektivitas ventilasi alami ditentukan oleh kondisi luar ruangan dan iklim mikro yang berlaku serta oleh desain bangunan dan penggunaan bangunan. Oleh karena itu, kinerja ventilasi alami sangat bergantung pada proses desain dan perlu dirancang bersama dengan bangunan [11].

Berdasarkan kondisi alam dan keinginan untuk mendapatkan kenyamanan termal yang maksimal akan tetapi tetap mempertimbangkan penghematan energi, maka perancangan lingkungan alun-alun desa Caturharjo menggunakan prinsip artsitektur tropis. Prinsip ini merupakan jalan keluar untuk beberapa masalah yang terdapat di Kawasan kantor desa, yaitu :

1. Masih terdapat ruang luar yang belum tertata dengan baik

2. Kurangnya ruang public di kompleks kantor desa

3. Memiliki potensi site yang cukup luas namun belum tata/rancang secara terpadu sebagai fasilitas umum yang mampu menyediakan ruang public

4. Kegiatan di ruang luar belum dibuatkan penataan ruangnya dengan baik

5. Belum terdapat landmark di kawasan kantor desa

6. Memiliki potensi lahan yang belum tertata namun belum dikembangkan sebagai ruang untuk public pada level desa

\section{Metode Pengabdian (Heading 1)}

Penataan Lingkungan Kantor Desa Caturharjo dilakukan dengan tahapan sebagai berikut:

1. Persiapan, meliputi penyusunan rencana kegiatan yang dilakukan oleh tim, dan koordinasi dengan kantor desa mengenai kebutuhan yang diinginkan berada di alunalun desa Caturharjo..

2. Pengumpulan data primer dan sekunder, meliputi observasi lapangan, tinjauan tapak, dokumentasi, dan wawancara dengan kantor desa.
3. Studi Literatur tentang perancangan tapak, wisata alam, regulasi terkait di Kabupaten Bantul dan analisis sebagai landasan disain.

Tahapan pelaksanaan program Abdimas dilakukan secara sistematis:

a) SWOT (strengths, weakness, opportunity, threats). Setiap permasalahan yang telah dipetakan merupakan masalah di lapangan.

b) Setiap masalah dianalisis secara cermat terkait dengan factor masalah tersebut melalui diskusi solusi dengan mitra.

c) Masalah tersebut dicari solusinya, melalui rembug mitra.

d) Bentuk solusi nya berupa pelatihan kelompok agar program dapat berjalan, dan disain fasilitas pendukung.

e) Akhir tahap Abdimas dilakukan evaluasi pembentukan kelompok sadar wisata dan media promosi dan fasilitas Metode pelaksanaan kegiatan ini dapat digambarkan sebagai berikut :

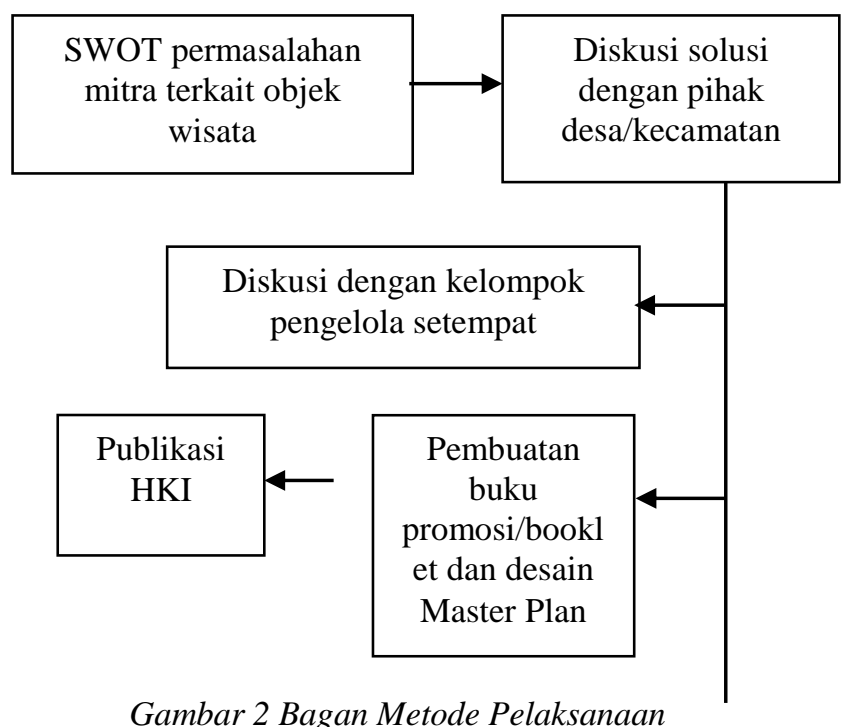

Keterlibatan dari pihak mitra yakni: Kepala Desa, Carik Desa, Kepala Dukuh dan tokoh masyarakat dimulai dari pertemuan koordinasi dalam bentuk kegiatan diskusi tentang identifikasi permasalahan dan potensi wilayah. Pertemuan selanjutnya membahas bentuk partisipasi masyarakat baik partisipasi ide-ide/gagasan pengembangan, partisipasi tenaga, serta rencana transfer pengetahuan pengelolaan isi media promosi.

\section{HASIL DAN PEMBAHAAN (HEADING 1)}

Berdasarkan dokumen Rencana Detil Tata Ruang Kecamatan Pandak, kawasan lingkungan kantor desa caturharjo termasuk kawasan perkantoran, sedangkan lapangan di sisi Barat kantor merupakan kawasan ruang terbuka hijau dan olah raga [12]. Analisis SWOT kawasan lingkungan kantor desa Caturharjo sebagai berikut:

a. Kekuatan:

S1 :Memiliki area terbuka/hijau dan pemandangan persawahan 
S2 : Memiliki tempat untuk berwisata.

b. Kelemahan:

W1 :Masih asli dan belum ditata.

W2 :Masih belum ada fasilitas pendukung publik.

W3 :Pemerintah setempat belum memiliki perencanaan c. Peluang:

O1 :Tempat wisata yang memiliki area foto dan pemandangan yang menarik dapat menjadi daya Tarik masyarakat.

O2 :Objek wisata dan area olah raga di wilayah Bantul mulai mampu menarik minat masyarakat.

d. Tantangan

$\mathrm{T} 1$ :Lahan masih berkontur asli, perlu penataan

T2 :Belum ada prasarana sarana pendukung diluar site Strategi SWOT

a. SO1:Mempromosikan melalui disain yang menarik.

b. SO2:Melakukan disain penambahan fasilitas.

c. ST1:Melakukan perbaikan kualitas tapak.

d. ST2:Menambah perabot taman dan jalan

e. WO1:Meningkatkan fasilitas bagi pengunjung.

f. WO2:Melibatkan warga dalam aktivitas ekonomi seperti pembukaan warung

g. WT1:Meningkatkan fasilitas dan tata hijau,

h. WT2:Melakukan gotong royong/swadaya

Perancangan Alun-alun desa Caturharjo menggunakan prinsip Arsitektur Tropis. Prinsip ini cocok digunakan untuk bangunan yang berada di iklim tropis. Prinsip imi dapat digunakan untuk desain yang mampu mengurangi penggunaan konsumsi energi pada bangunan, terutama beban pendinginan. Negara-negara di kawasan AsiaPasifik telah mengadopsi desain vernakular yang menyesuaikan dengan kebutuhan iklim mereka selama berabad-abad. Misalnya, langit-langit yang tinggi menunjukkan pemahaman tentang stack effect. Rumah Melayu memasang overhang atap besar dan orang India Barat menggunakan beranda untuk mengurangi kelebihan matahari. Solusi desain ini dapat memaksimalkan ventilasi alami bahkan pada saat turun hujan denga tetap membuka jendela. Orang Samoa dahulu kala tidak memasang dinding untuk memungkinkan angin yang bertiup bebas. Banyaknya jendela rumah Melayu bertujuan untuk memaksimalkan ventilasi silang [13].

Arsitektur tropis bekerja untuk mencapai kenyamanan termal melalui penggunaan elemen desain, seperti pelindung matahari, dinding rongga, overhang, insulasi atap dan dinding, dan bahkan peneduh dari pepohonan. Prinsip desain arsitektur tropis meliputi: evaluasi wilayah; elemen iklim; pilihan situs; orientasi sol-udara; pengendalian matahari terhadap lingkungan dan bangunan; bentuk, efek angin dan pola aliran udara; efek termal bahan; dan perencanaan heliothermic. Selain itu, ventilasi silang maksimum, pencahayaan alami, kisi-kisi dan bahan alami merupakan elemen kunci untuk mengoptimalkan ventilasi alami untuk mendinginkan bangunan tropis [13].

Iklim tropis mengalami curah hujan dan kelembaban yang tinggi bersama dengan sinar matahari sepanjang tahun, suhu di malam hari biasanya berkisar antara $25-27^{\circ} \mathrm{C}$ dan bahkan lebih hangat di malam hari, dari $25-30^{\circ} \mathrm{C}$. Kondisi ini tidak hanya mempengaruhi budaya warga negara tropis, tetapi juga mempengaruhi cara mereka membangun tempat tinggal dan konstruksi lainnya. Ventilasi adalah salah satu dari banyak hal yang harus direncanakan secara menyeluruh saat membangun di iklim panas atau tropis. Ini adalah sesuatu yang dapat dicapai melalui desain pasif, proses pengaturan suhu dalam ruangan dengan membuat iklim bekerja sesuai keinginan. Bangunan satu lantai yang berorientasi tegak lurus arah angin dengan bukaan di kedua sisinya akan meningkatkan sirkulasi udara alami. Selain itu, ini akan membawa cahaya alami dan akan memungkinkan ventilasi silang jika diorientasikan dengan benar. Dengan desain yang tepat, pencahayaan buatan, sistem pendingin, dan ventilasi mekanis tidak terlalu dibutuhkan [14].

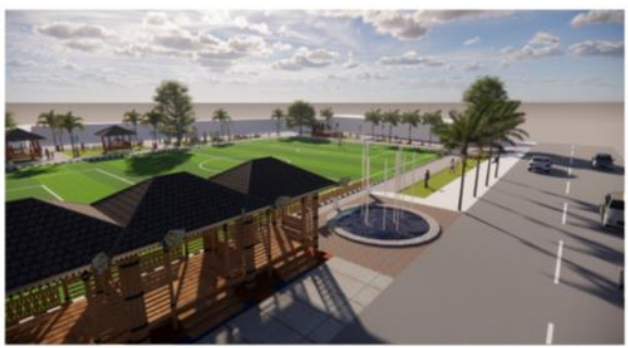

Gambar 3 . Tampak Perspektif (Sumber: digambar oleh Riana, 2021)

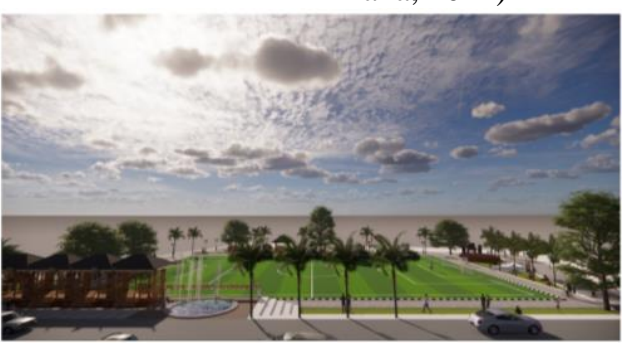

Gambar 4 . Tampak Perspektif (Sumber: digambar oleh Riana, 2021)

Sesuai dengan hasil analisis tapak, pengolahan tata massa bangunan menyesuaikan dengan kontur tapak yang relative pada tapak yang berada di sisi Barat kantor Desa (gambar 3). Tapak yang ada di lokasi merupakan tanah yang tidak memiliki kontur, sehingga diberikan gazebo di area sekitar Alun-alun (gambar 4).

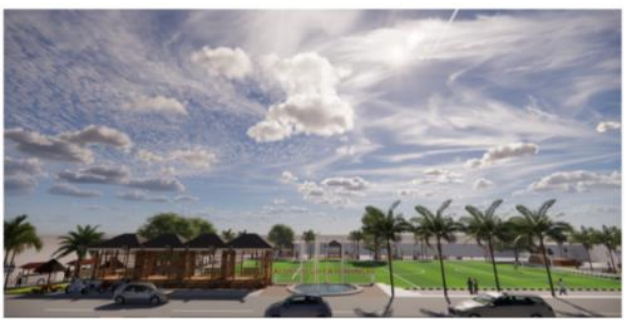

Gambar 5 . Tampak Area Gazebo (Sumber: digambar oleh Riana, 2021) 


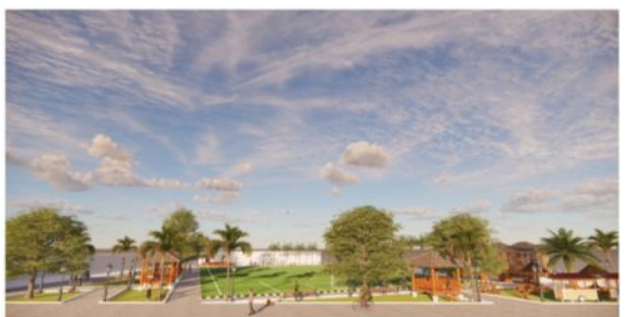

Gambar 6 . Tampak Perspektif (Sumber: digambar oleh Riana, 2021)

Pengolahan site mengikuti topografi lahan yang merupakan lapangan yang belum pernah ditata, dan mewadahi fasilitas umum demi memberikan kenyaman kepada pengunjung (gambar 5). Pemandangan persawahan juga dimanfaatkan sebagai view utama dalam penataan ruang (gambar 6). Berdasarkan regulasi Peraturan Guberbur DIY no.1/2017 tentang Arsitektur Bangunan Berciri Daerah maka konsep bentuk fasilitas pendukung alun-alun kantor desa Caturharjo ini mengacu pada arsitektur tradisional Yogyakarta [15].

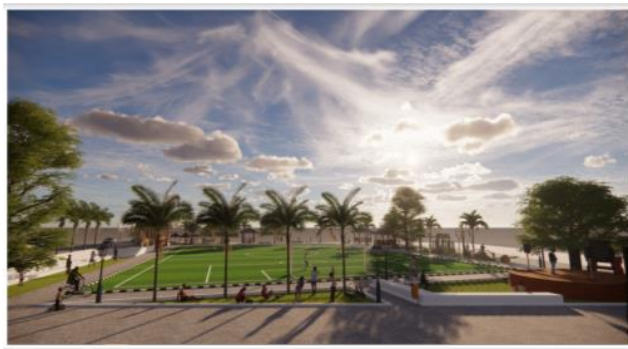

Gambar 7. Area duduk-duduk (Sumber: digambar oleh Riana, 2021)

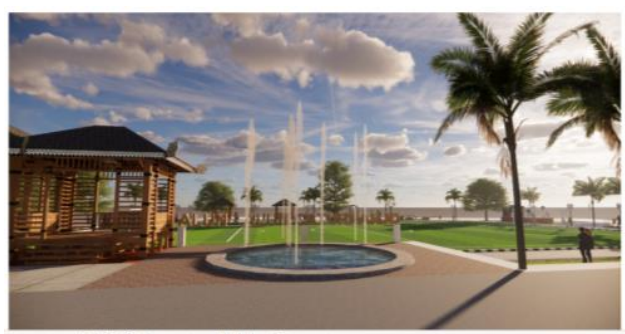

Gambar 8. Area Air Mancur (Sumber: digambar oleh Riana, 2021)

Fasilitas pendukung pada area duduk-duduk dan gazebo mengambil tema kombinasi material kayu dan dipadukan dengan material batu (gambar 7). Disain fasilitas area kuliner, air mancur, gubug-gubug untuk duduk-duduk mengambil konsep arsitektur lokal tropis (gambar 8). Penggunaan air mancur yang diletakkan di dekat gazebo dapat membantu memberikan kenyamanan termal pada orang yang berada di dalam gazebo dan di sekitar air mancur tersebut. Hal tersebut sesuai dengan teori yang ditunjukkan oleh Murakawa dkk. Pada teori itu mengamati bahwa suhu udara bisa menurun lebih dari $5^{\circ} \mathrm{C}$ di sekitar sungai di musim hangat dan efek ini juga bisa diperkuat melalui angin [16]. Di musim panas, air memiliki fungsi pendinginan dan meningkatkan perasaan nyaman secara termal pada manusia. Selain itu, efek ini akan diperbesar secara maksimal di area dengan jarak 10-20 m dari sungai [17]. Singkatnya, perhatian besar harus diberikan pada perencanaan dan pembangunan air ketika merencanakan daerah pemukiman. Mengatur adanya air pada posisi yang tepat dapat sepenuhnya meningkatkan lingkungan termal di sekitarnya. Terlebih lagi, posisi sentral biasanya merupakan zona aktivitas orang. Pengaturan peletakan air dapat menjadi kondusif yang efisien untuk menciptakan situasi kehidupan yang nyaman dengan meningkatkan tingkat kenyamanan termal [18].

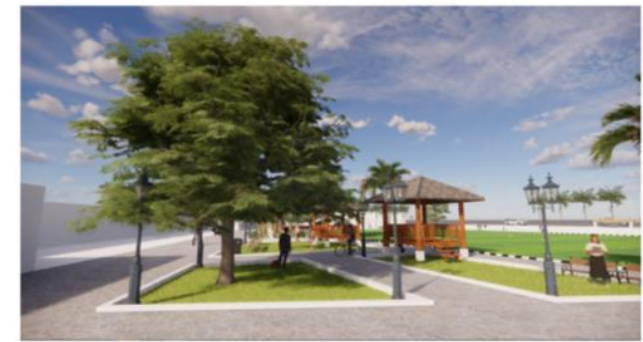

Gambar 9. Area Jalan Setapak (Sumber: digambar oleh Riana, 2021)

Desain ini juga ingin memberikan kesan ramah lingkungan dengan menggunakan grass block yang dipadukan dengan vegetasi lokal pada permukaan jalan setapak (gambar 9). Standar yang digunakan untuk penataan jalan menuju kawasan yaitu standar yang ditetapkan oleh Dinas Pekerjaan Umum. Di area sekitar alun-alun diberikan vegetasi tanaman perindang untuk mengurangi panas matahari yang ada di wilayah tersebut dan sebagai pengarah jalan [19].

Hal ini berfungsi untuk menurunkan suhu yang ada di lingkungan sekitar alun-alun. Peningkatan vegetasi perkotaan menyebabkan penurunan suhu udara dan permukaan. Secara khusus, pohon mempengaruhi lingkungan termal dengan memberikan naungan, mencegat radiasi dengan kanopi mereka dan mengurangi suhu permukaan, diikuti dengan perpindahan panas melalui konveksi dari daerah yang lebih hangat [20] [21]. Manfaat dari penggunaan vegetasi adalah vegetasi mampu mengubah pola aliran angin di jalanan [22][23]. Hal ini menyebabkan angin dapat diarahkan kea rah alun-alun dan membuat area alun-alun menjadi lebih sejuk dan suhunya menjadi lebih rendah daripada lingkungan di sekitarnya. Vegetasi juga meningkatkan polutan yang dibuang udara melalui pengendapan atau pengambilan melalui stomata daun. Pepohonan dapat meredam kebisingan lalu lintas, khususnya di dekat jalan atau membuka jalan yang sibuk [22][23].

Vegetasi direkomendasikan sebagai strategi mengurangi panas di suatu lingkungan [24] [25]. Strategi ini dianggap lebih baik daripada menggunakan bahan albedo tinggi di tanah untuk meningkatkan kenyamanan termal pejalan kaki [20] [21]. Kenyamanan termal luar ruangan diubah oleh vegetasi melalui proses evapotranspirasi, refleksi matahari, perlindungan matahari (naungan) dan perubahan aliran angin. Secara khusus, tumbuhan menyediakan pendinginan transpirasional karena energi matahari yang diserap menyebabkan peningkatan panas laten (air dari tumbuhan diuapkan ke atmosfer) sehingga mendinginkan permukaan daun dan udara di sekitarnya [26][27] [28]. Selain itu, keberadaan vegetasi meningkatkan reflektifitas 
gelombang pendek kota secara keseluruhan. Oleh karena itu, tumbuhan menyerap dan menyimpan lebih sedikit panas dibandingkan bahan bangunan. Selain itu, naungan pohon mencegah kenaikan suhu udara dan permukaan karena pohon mencegat radiasi matahari [29].

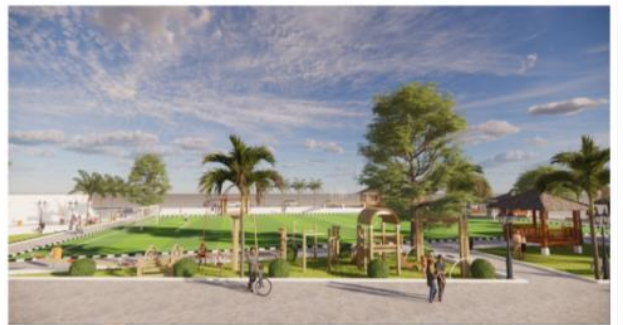

Gambar 10. Area Bermain Anak (Sumber: digambar oleh Riana, 2021)

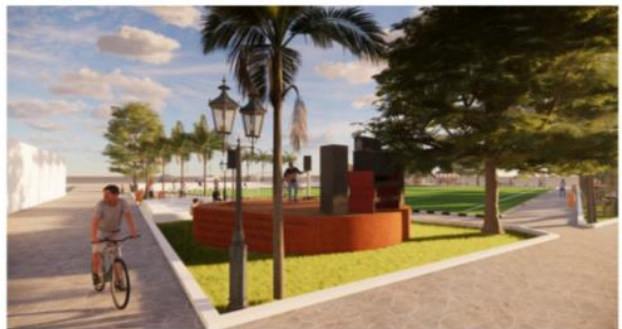

Gambar 11. Area Panggung (Sumber: digambar oleh Riana, 2021)

Desain lain yang dilakukan di alun-alun tersebut adalah penataan fasilitas perabot taman yang meliputi lampu penerangan taman dan jalan, tempat duduk, papan petunjuk jalan dan informasi, serta rambu lain yang memberikan fasilitas bagi pengunjung sesuai aturan menurut Ditjen Binamarga dan Direktorat Pembinaan Jalan dan berdasarkan Peraturan Menteri Pekerjaan Umum nomor 6 tahun 2007. Hal tersebut diterapkan pada perancangan di seluruh area alunalun, terutama pada area bermain anak dan area panggung (gambar 10 dan gambar 11).

Furnitur jalan adalah komponen yang direncanakan untuk kecantikan, sekaligus untuk memberikan hiburan, relaksasi, dan jaminan dari dampak luar. Furnitur jalan sangat penting karena kegunaannya, serta merupakan bagian integral dan ciri dari komponen visual ruang kota. Furnitur jalanan digunakan terutama untuk alasan visual yang mempengaruhi ruang secara positif, jadi selain fungsional, perhatian estetika harus dipertimbangkan sehingga tidak akan berdampak negatif pada sekitarnya dan akan memberi identitas pada perkotaan tempat mereka berada. Furnitur jalan akan lebih menarik jika memiliki ritme, keseimbangan, kesatuan dan perpaduan antara kegunaan dan keindahan dalam konfigurasinya; dan jika ia memiliki struktur geometris, warna, tekstur [30].

Furnitur jalan merupakan salah satu aspek fisik, dan merupakan bagian dari elemen lansekap buatan manusia atau lansekap keras, yang merupakan salah satu pembentuk identitas suatu tempat pada suatu daerah [31][32][33]. Pada penempatannya di lanskap jalan, furnitur jalan dapat berfungsi sebagai elemen dekoratif; furnitur untuk bersantai dan periklanan [31]. Kualitas suatu objek wisata yang menarik dapat diraih dengan perencanaan dan perancangan furniture jalan yang memperhatikan unsur lingkungan sekitar, menyatu sebagai komposisi yang menarik. Tidak lengkapnya elemen furniture jalan pada suatu wilayah menyebabkan penyimpangan area [34]. Hal ini didukung dengan prinsip place identity, dimana furniture jalan yang tidak lengkap akan menyebabkan ketidaknyamanan pengguna [35].

Desain tempat duduk pada taman menggunakan material yang nyaman digunakan oleh pengunjung, memiliki perawatan yang mudah, dan tahan lama. Hal ini dikarenakan pada area alun-alun mewadahi berbagai aktivitas masyarakat. Fasilitas yang ada di alun-alun adalah area kuliner (gambar 12), area olah raga (gambar 13) dan area parkir (gambar 14). Fasilitas tersebut diberikan karena alun-alun merupakan area utama warga Caturharjo untuk melakukan interaksi sosial.

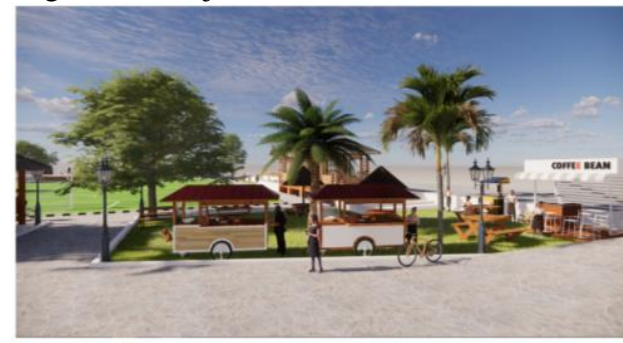

Gambar 12. Area Kuliner (Sumber: digambar oleh Riana, 2021)

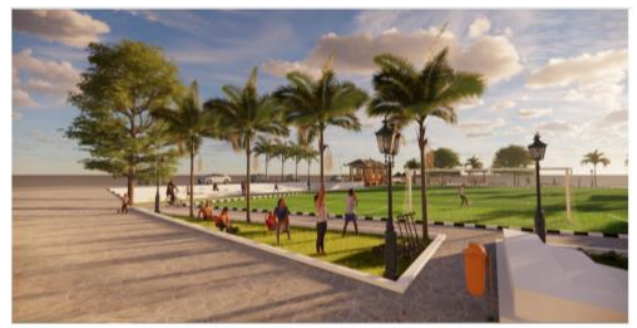

Gambar 13. Area Olah Raga (Sumber: digambar ooleh Riana, 2021)

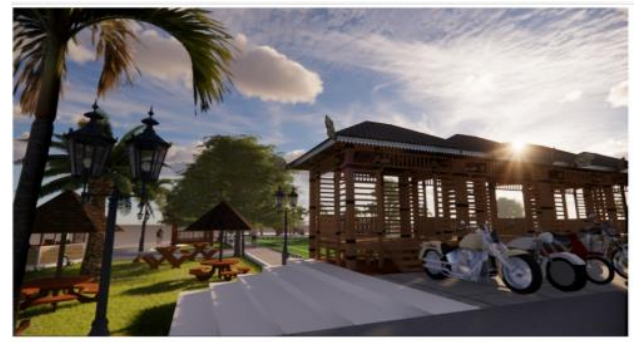

Gambar 14. Area Parkir dan Kios (Sumber: digambar ooleh Riana, 2021)

Tempat duduk menciptakan lingkungan terbuka yang menyenangkan, dapat digunakan, dan dinamis di mana individu dapat beristirahat, bergaul, membaca, saling berinteraksi. Tempat duduk membuat tempat di mana individu dapat melihat dan dilihat. Menambahkan tempat duduk untuk orang di ruang publik adalah peningkatan sederhana yang dapat dilakukan oleh orang, kelompok kelompok, kawasan bisnis, dan lainnya, secara teratur sebagai komponen dari usaha memaksimalkan jalan umum [30]. 
Pada Alun-alun juga terdapat ruang serbaguna. Pada Ruang Serbaguna (pendapa) didesain semi terbuka (tanpa dinding) untuk memaksimalkan view yang ada di sekitar lingkungan alun-alun. Ruang serbaguna disediakan sebagai ruang pertemuan yang besifat semi terbuka untuk mewadahi kegiatan pengunjung. Material yang digunakan adalah material alami seperti bamboo dan kayu. Hal ini sesuai dengan konsep Arsitektur Tropis yang lebih mengedepankan penggunaan material alami.

Salah satu keunggulan teknik dan bentuk bangunan tradisional adalah kelenturannya dan kapasitas pengondisian alaminya. Untuk memfosilkan pola-pola tradisional untuk zaman kontemporer tidaklah tepat, mengingat kebutuhan bangunan saat ini, seperti halnya mengabaikan teknik bangunan tradisional [36]. Prioritas terpenting dari bangunan adalah ketahanannya. Bangunan tradisional memiliki sejumlah karakteristik tahan angin dan termal. Rumah-rumah dibangun dari lalang palem dengan atap berpinggul yang relatif curam, terjalin dengan baik tanpa jendela dan sedikit pintu. Porositas bahan bangunan mencegah penumpukan panas yang berlebihan di dalam ruang interior. Penggunaan material tradisional seperti kayu dan bambu untuk struktur rangka tanpa dinding membuat angin dapat dengan mudah bertiup melalui struktur tersebut; dinding anyaman bambu dapat digunakan untuk menutup bangunan bila diperlukan [37].

\section{KESIMPULAN}

Penataan Alun-alun Lingkungan Kantor Desa Caturharjo mempertimbangkan potensi dan masalah sekitar tapak berupa view persawahan, kantor dan pendidikan serta saluran irigasi. Disain fasilitas pendukung melibatkan peran warga sebagai pengguna dan staf kantor desa sebagai pemilik lingkungan. Kesadaran dan respon staf kantor desa dan warga terhadap potensi ruang terbuka di desa Caturharjo memberi manfaat peningkatan identitas desa dan kesejahteraan waraga melalui keterlibatan masyarakat dalam kepengelolaan potensi area rekreasi dan olah raga ini. Perancangan penataan lingkungan kantor desa Caturharjo ini tidak mengubah bentang alam yang ada.

Kegiatan Pengabdian kepada masyarakat ini juga mendorong peran serta masyarakat khususnya dalam penyediaan faslitas pariwisata di desa Caturharjo. Adanya penataan fasilitas pariwisata ini mampu membuat objek wisata berkembang sebagai area wisata warga desa dan wisatawan dari wilayah lain yang menarik dan berkelanjutan.

\section{UCAPAN TERIMAKASIH}

Ucapan terimakasih kepada LPPM Universitas Atma Jaya Yogyakarta atas dukungan dana Pengabdian kepada Masyarakat Semester Genapl TA 2020/2021.

\section{DAFTAR PUSTAKA}

[1] P. K. Bantul, "Bantul Smart City," Bantul, 2018.

[2] C. Hernández Pezzi, Un vitruvio ecológico: principios y práctica del proyecto arquitectónico sostenible. Barcelona, 2012.

[3] D. L. Jones, Arquitectura y entorno. El diseño de la construcción bioclimática. Barcelona: Art Blume, 2002.

[4] M. Stiller, Quality lighting for high performance buildings. Lilburn: Fairmont Press, 2012.

[5] T. Schröpfer, Ecological urban architecture: qualitative approaches to sustainability. Basel: Birkhauser Architecture, 2012.

[6] R. Lopez, The built environment and public health. San Francisco: Jossey-Bass., 2012.

[7] M. Alperytė, I., \& Išoraitè, Developing a City Brand. Journal of Intercultural Management, 2020.

[8] B. Talarosha, "Menciptakan Kenyamanan Thermal Dalam Bangunan,” J. Sist. Tek. Ind., vol. 6, no. 3, pp. 148-158, 2005.

[9] D. D. Harisdani and F. Kartika, "Application of Tropical Architecture in Convention Hall Design,” Int. J. Archit. Urban., vol. 2, no. 3, pp. 263-274, 2018, doi: 10.32734/ijau.v2i3.658.

[10] J. M. C. Lainez, "The quest for light in Indian architectural heritage," J. Asian Archit. Build. Eng., vol. 7, no. 1, pp. 39-46, 2008, doi: 10.3130/jaabe.7.39.

[11] P. Heiselberg, "Natural Ventilation Design," Int. J. Vent., vol. 2, no. 4, pp. 295-312, 2004, doi: 10.1080/14733315.2004.11683674.

[12] Dinas Pekerjaan Umum, "Rencana Detil Tata Ruang Kecamatan Pandak," Bantul, 2014

[13] V. Trucks, V. Euro, S. C. R. Euro, N. Oxide, V. Table, and E. E. Regulations, "Fact sheet," vol. 1, no. X, pp. 1-2, 2011.

[14] "Tropical Architecture: The Art of Living in the Tropics." https://indonesiadesign.com/story/tropical-architecture (accessed Apr. 16, 2021)

[15] Pemerintah Daerah Istimewa Yogyakarta, “Arsitektur Berciri Daerah," Yogyakarta, 2017.

[16] S. Murakawa, T. Sekine, K. ichi Narita, and D. Nishina, "Study of the effects of a river on the thermal environment in an urban area," Energy Build., vol. 16, no. 3-4, pp. 993-1001, 1991, doi: 10.1016/03787788(91)90094-j.

[17] R. Sun and L. Chen, "How can urban water bodies be designed for climate adaptation?," Landsc. Urban Plan., vol. 105, no. 1-2, pp. $27-$ 33, 2012, doi: 10.1016/j.landurbplan.2011.11.018.

[18] L. Yang, X. Liu, and F. Qian, "Research on water thermal effect on surrounding environment in summer," Energy Build., vol. 207, p. 109613, 2020, doi: 10.1016/j.enbuild.2019.109613.

[19] Kementerian Menteri Pekerjaan Umum, "Pedoman Penataan Vegetasi dan Perabot Jalan," Jakarta, 2007.

[20] M. Taleghani, "Outdoor thermal comfort by different heat mitigation strategies- A review," Renew. Sustain. Energy Rev., vol. 81, no. March, pp. 2011-2018, 2018, doi: 10.1016/j.rser.2017.06.010.

[21] M. Santamouris et al., "Passive and active cooling for the outdoor built environment - Analysis and assessment of the cooling potential of mitigation technologies using performance data from 220 large scale projects," Sol. Energy, vol. 154, pp. 14-33, 2017, doi: 10.1016/j.solener.2016.12.006.

[22] J. A. Salmond et al., "Health and climate related ecosystem services provided by street trees in the urban environment," Environ. Heal. A Glob. Access Sci. Source, vol. 15, no. Suppl 1, 2016, doi: 10.1186/s12940-016-0103-6.

[23] S. J. Livesley, E. G. McPherson, and C. Calfapietra, "The Urban Forest and Ecosystem Services: Impacts on Urban Water, Heat, and Pollution Cycles at the Tree, Street, and City Scale," J. Environ. Qual., vol. 45, no. 1, pp. 119-124, 2016, doi: 10.2134/jeq2015.11.0567.

[24] E. Jamei, P. Rajagopalan, M. Seyedmahmoudian, and Y. Jamei, "Review on the impact of urban geometry and pedestrian level greening on outdoor thermal comfort," Renew. Sustain. Energy Rev., vol. 54, pp. 1002-1017, 2016, doi: 10.1016/j.rser.2015.10.104.

[25] A. S. Nouri, J. P. Costa, M. Santamouris, and A. Matzarakis, "Approaches to outdoor thermal comfort thresholds through public space design: A review," Atmosphere (Basel)., vol. 9, no. 3, 2018, doi: 10.3390/atmos9030108.

[26] C. Gromke, B. Blocken, W. Janssen, B. Merema, T. van Hooff, and H. Timmermans, "CFD analysis of transpirational cooling by vegetation: Case study for specific meteorological conditions during a heat wave in Arnhem, Netherlands," Build. Environ., vol. 83, pp. 11-26, 2015, doi: 10.1016/j.buildenv.2014.04.022.

[27] R. Buccolieri, J. L. Santiago, E. Rivas, and B. Sanchez, "Review on urban tree modelling in CFD simulations: Aerodynamic, deposition 
and thermal effects," Urban For. Urban Green., vol. 31, no. February, pp. 212-220, 2018, doi: 10.1016/j.ufug.2018.03.003.

[28] Y. Yang, E. Gatto, Z. Gao, R. Buccolieri, T. E. Morakinyo, and H. Lan, "The 'plant evaluation model' for the assessment of the impact of vegetation on outdoor microclimate in the urban environment," Build. Environ., vol. 159, no. May, 2019, doi: 10.1016/j.buildenv.2019.05.029.

[29] K. R. Gunawardena, M. J. Wells, and T. Kershaw, "Utilising green and bluespace to mitigate urban heat island intensity," Sci. Total Environ., vol. 584-585, pp. 1040-1055, 2017, doi: 10.1016/j.scitotenv.2017.01.158.

[30] A. H. Radwan, A. Abdel, and G. Morsy, "The importance of integrating street furniture in the visual imageof the city," vol. X, 2014.

[31] C. R. Mourthé and J. B. De Menezes, "Ergonomics methodology for comparative study of street furniture in different cities," Proc. XIVth Trienn. Congr. Int. Ergon. Assoc. 44th Annu. Meet. Hum. Factors Ergon. Assoc. 'Ergonomics New Millenn., pp. 28-31, 2000, doi: $10.1177 / 154193120004400807$.

[32] N. H. Ja'afar, A. B. Sulaiman, and S. Shamsuddin, "The Contribution of Landscape Features on Traditional Streets in Malaysia," Procedia - Soc. Behav. Sci., vol. 50, no. July, pp. 643-656, 2012, doi: 10.1016/j.sbspro.2012.08.067.

[33] N. Ujang, "Place Attachment and Continuity of Urban Place Identity," Procedia - Soc. Behav. Sci., vol. 49, no. January, pp. 156-167, 2012, doi: 10.1016/j.sbspro.2012.07.014

[34] Y. Ye, T. Fei, and H. Mei, "The Relationship between Walkability and Environment Characteristics in Cold Region Cities: Case Study in Harbin," IOP Conf. Ser. Earth Environ. Sci., vol. 63, no. 1, 2017, doi: 10.1088/1755-1315/63/1/012053.

[35] N. Ginting, N. Vinky Rahman, A. Delianur Nasution, M. Nawawiy Loebis, and F. A. Sinaga, "Street furniture concept in Pasar Buah and Bukit Gundaling Based on place identity," IOP Conf. Ser. Earth Environ. Sci., vol. 126, no. 1, 2018, doi: 10.1088/17551315/126/1/012195.

[36] T. T. Amasuomo and G. Baird, "Evolution of buildings in four tropical regions with regards to thermal comfort Occupancy Evaluation of office environments View project Evolution of buildings in four tropical regions with regards to thermal comfort," no. December 2016, pp. 617-626, 2016, [Online]. Available: https://www.researchgate.net/publication/316367220.

[37] J. Campbell, "Islandness: Vulnerability and Resilience in Oceania," Shima Int. J. Res. into Isl. Cult., vol. 3, no. 1, pp. 85-97, 2009.

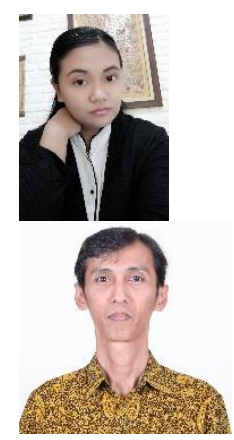

\section{PenUlis (HEADING 5)}

Nimas Sekarlangit, prodi Arsitektur, Fakultas Teknik, Universitas Atma Jaya Yogyakarta.

Amos Setiadi² ${ }^{2}$, prodi Teknik Sipil, Fakultas Teknik, Universitas Atma Jaya Yogyakarta.

Novita Rachmanti Putri, prodi Manajemen, Fakultas Bisnis dan Ekonomi, Universitas Atma Jaya Yogyakarta. 